\title{
Agricultural extension and its effects on farm productivity and income: insight from Northern Ghana
}

\author{
Gideon Danso-Abbeam ${ }^{1 *}$ (D) Dennis Sedem Ehiakpor ${ }^{1}$ and Robert Aidoo ${ }^{2}$
}

\begin{abstract}
Background: In agricultural-dependent economies, extension programmes have been the main conduit for disseminating information on farm technologies, support rural adult learning and assist farmers in developing their farm technical and managerial skills. It is expected that extension programmes will help increase farm productivity, farm revenue, reduce poverty and minimize food insecurity. In this study, we estimate the effects of extension services on farm productivity and income with particular reference to agricultural extension services delivered by Association of Church-based Development NGOs (ACDEP).

Methods: The study used cross-sectional data collected from 200 farm households from two districts in the Northern region of Ghana. The robustness of the estimates was tested by the use of regression on covariates, regression on propensity scores and Heckman treatment effect model.

Results: The study found positive economic gains from participating in the ACDEP agricultural extension programmes. Apart from the primary variable of interest (ACDEP agricultural extension programme), socio-economic, institutional and farm-specific variables were estimated to significantly affect farmers'farm income depending on the estimation technique used.

Conclusions: The study has reaffirmed the critical role of extension programmes in enhancing farm productivity and household income. It is, therefore, recommended that agricultural extension service delivery should be boosted through timely recruitment, periodic training of agents and provision of adequate logistics.
\end{abstract}

Keywords: Agricultural extension, ACDEP, Heckman treatment effect, Productivity, Regression on propensity scores

\section{Background}

The millennium development goals (MDGs) of reducing hunger and to promote food security are rooted in increasing agricultural productivity, especially from the crop sector. This is because agriculture is considered as the engine of growth in many developing economies, particularly in sub-Saharan Africa (SSA). The policy direction of growth and poverty reduction strategy (GPRS II) formulated by Ghana was to achieve accelerated and sustainable growth and poverty reduction through

\footnotetext{
*Correspondence: dansoabbeam@uds.edu.gh

1 Department of Agricultural and Resource Economics, University

for Development Studies, Tamale, Ghana

Full list of author information is available at the end of the article
}

agricultural productivity. Although poverty had declined by $7.7 \%$ over the years (2005-2013), about $25 \%$ of Ghana's population is still poor while under a tenth of the population are living in extreme poverty [1]. This suggests that the role of agriculture has not been sufficient to elevate many people above the poverty line, especially the rural folks who contribute immensely to agricultural production in Ghana. Ghana's agricultural sector, which employs about $42 \%$ of the workforce, is dominated by smallholder farmers (about $90 \%$ farming on less than 2 hectares of land) who are using traditional production methods and farm inputs [2]. Asfaw et al. [3] argue that achieving productivity growth in the agricultural sector can only be successful through the development and dissemination of improved agricultural technologies to these smallholder 
farmers in the rural areas. Rural farmers farming on small hectares of land can be attributed to conditions such as lack of adequate credit, lack of access to product market, lack of adequate extension contacts, among others. Among these constraints, inadequate extension services have been identified as one of the main limiting factors to the growth of the agricultural sector and rural community development at large [3]. With recent threats of climate change and the rapid advancement in technology, more farmers require capital investment in agriculture and human capacity development to at least continue to make their living out of farming. Thus, the role of agricultural extension today goes beyond the transfer of technology and improvement in productivity, but also, it includes improvement in farmers' managerial and technical skills through training, facilitation and coaching, among others.

Incognizant of these problems, the government of Ghana through the Ministry of Food and Agriculture (MoFA) over the years has invested so much in building the capacities of smallholder farmers through agricultural extension programmes. Other stakeholders in the agricultural sector such as international and local funding agencies, non-governmental organizations and financial institutions have and continue to make investments in the delivery of extension services to farmers. One of the prominent NGOs that have been implementing extension programmes in Northern Ghana is the Association of Church-based Development NGOs (ACDEP). ACDEP is a network of over 40 , mostly, but not only church sponsored development NGOs in Northern Ghana with the vision of improving the economic well-being of its actors, particularly farmers through improved farm technology and access to input and output markets. The ACDEP NGOs are also engaged in other fields such as primary health care, HIV/AIDS, water and sanitation, rural enterprise development for women and value chains. One of the key components of ACDEP programmes in the field of agriculture is the delivery of agricultural extension services.

The ACDEP agricultural extension programmes include capacity building in good agricultural practices (GAPs), creating linkages among the value chain actors (input dealers, farmers, wholesalers and retailers) and other value addition techniques. ${ }^{1}$ Thus, wider dissemination of information regarding farmer skill development, the use of improved farm technologies, general farm management practices and easy access to input and output markets have been the fundamental principles

\footnotetext{
${ }^{1}$ The study used "ACDEP extension programmes" and "ACDEP agricultural extension programmes" interchangeably.
}

underlying delivery of ACDEP agricultural extension services. All these are geared towards improvement in productivity, reduction in poverty and enhancement in food security. ${ }^{2}$ Given the scale of investment from ACDEP, the value for money regarding an increase in farm income is an important policy question. In this study, we hypothesized that participation in ACDEP agricultural extension programmes positively affects the welfare of the participating farm households through improvement in farm productivity and income. Many studies had dealt with issues relating to improving agricultural technologies such as improved crop varieties, adoption of fertilizer, etc. in Ghana [4-8]. Also, some other studies had focused on the impact of government extension programmes concerning the use of technology, adoption rates, farm productivity and efficiency, and farm output levels [9]. These studies had provided excellent information on factors shaping adoption and adoption intensities of farm technologies. However, rigorous studies on impact evaluation of agricultural extension services delivered by non-governmental organizations such as ACDEP on smallholders' farm productivity and income remain very rare in the Ghanaian agricultural literature. Thus, there are many gaps with regard to what is known about the effects of extension services on the productivity and income of farmers - the body of empirical evidence does not match the scale of implementation, particularly in Ghana's agricultural sector. Hence, the aim of the study is to estimate the effects of agricultural extension services with particular reference to ACDEP on the farm productivity and income of smallholder farmers in the ACDEP operational areas in the Northern region of Ghana.

\section{The role of extension services in agriculture}

Agricultural extension programmes have been one of the main conduits of addressing rural poverty and food insecurity. This is because, it has the means to transfer technology, support rural adult learning, assist farmers in problem-solving and getting farmers actively involved in the agricultural knowledge and information system [10]. Extension is defined by FAO [11] as; "systems that should facilitate the access of farmers, their organizations and other market actors to knowledge, information and technologies; facilitate their interaction with partners in research, education, agribusiness, and other relevant institutions; and assist them to develop their own technical, organizational and management skills and practices". By this definition, an extension is deemed as a primary

\footnotetext{
${ }^{2}$ Note: Information in this paragraph was sourced from ACDEP website (http://acdep.org/site/index.php/home-7/14-acdep-home/24-about-acdep) and its secretariat office in Tamale, Ghana.
} 
tool for making agriculture, its related activities as well as other economic activities more effective and efficient to meet the needs of the people. It is, therefore, regarded as a policy tool for promoting the safety and quality of agricultural products. Agricultural extension is aimed primarily at improving the knowledge of farmers for rural development; as such, it has been recognized as a critical component for technology transfer. Thus, agricultural extension is a major component to facilitate development since it plays a starring role in agricultural and rural development efforts [12].

Bonye et al. [12] argued that extension provides a source of information on new technologies for farming communities which when adopted can improve production, incomes and standards of living. Extension service providers make an innovation known to farm households, act as a catalyst to speed up adoption rate and also control change and attempt to prevent some individuals in the system from discontinuing the diffusion process [13]. In reaching farmers, extension officers demonstrate a technology to farmers but with much concentration on early adopters since the laggards would learn later from the early adopting farmers. Through extension services, farmers' problems are identified for further investigation and policy direction. Swanson [14] argued that extension service goes beyond technology transfer to general community development through human and social capital development, improving skills and knowledge for production and processing, facilitating access to markets and trade, organizing farmers and producer groups, and working with farmers towards sustainable natural resource management. Where market failures such as limited access to credit and non-competitive market structures that provide a disincentive to farmers to produce exist, extension services tend to provide solutions.

\section{Methods}

\section{The study area, data source and description of variables}

The study analyses the effects of ACDEP extension programmes on farm productivity and income using a sample obtained from the farming communities in the Tolon and Kumbugu districts of the Northern region of Ghana. The two districts are predominantly rural communities with the majority being smallholder farm households. Tolon district has a population of 72,990 (males constitute $49.8 \%$ while females constitute $50.2 \%$ ) of which 92.7\% are engaged in agriculture, while Kumbugu has a population of 39,341 (equally distributed between males and females, i.e. $50 \%$ ) of which $95.4 \%$ of the households are engaged in agriculture [15]. Crop farming is the main agricultural activities in the two districts with about 98\% engaged in it [15]. The districts are characterized by a single rainy season, which starts in late April with little rainfall, rising to its peak in July-August and declining sharply after that and coming to a complete halt in October-November. The dry season starts from November to March with day temperatures ranging from 33 to $39{ }^{\circ} \mathrm{C}$, while mean night temperature ranges from 20 to $26{ }^{\circ} \mathrm{C}$. The mean annual rainfall ranges between 950 and $1200 \mathrm{~mm}$.

The data were obtained mainly from primary sources, through the use of structured questionnaires. The study followed a multi-stage random sampling technique in selecting the two districts and communities from the Northern region and farm households from each community. In the first stage, the two districts were randomly selected from a number of ACDEP operational districts in the Northern region of Ghana. In the second stage, a random sampling was used to select four ACDEP operational communities from each district. Four non-ACDEP operational communities were selected from Tolon district, while three were selected from Kumbugu district. Thus, the survey covered fifteen communities, eight from Tolon and seven from Kumbugu. In the final stage, 10-15 maize farm households were randomly selected from each operational community, while 10-12 maize farm households were selected from each of the nonoperational communities. The total sample size of the study is 200 maize farm households consisting of 110 farm households who had participated in ACDEP extension programmes and 90 maize farm households who did not take part in the programme. Key informants such as some heads of departments of ACDEP office in Tamale, Ghana and community leaders were approached to discuss challenges and opportunities relating to the programme and how the programme can aid in increasing productivity and farm income.

Table 1 shows the descriptive statistics of the sampled farm households. Two main categories of variables are described here: the dependent variables (outcome variables) and the explanatory variables.

\section{Dependent variables}

The dependent variables consist of maize farm productivity (yields), maize farm income per hectare, total household income and household income per capita. Farm productivity is defined as the total output of maize in kilograms per hectare. ${ }^{3}$ The average yield of maize of the participating farm households is $1811 \mathrm{~kg}$ per hectare, while that of the non-participants is $1511 \mathrm{~kg}$ per hectare. Thus, there is no statistical difference between yields of participants and non-participants of the ACDEP agricultural extension programme. However, difference could

\footnotetext{
${ }^{3}$ In this study, farm productivity and farm yields are used interchangeably.
} 
Table 1 Descriptive statistics of the sampled farm households

\begin{tabular}{|c|c|c|c|c|}
\hline \multirow[t]{2}{*}{ Description of variables } & \multicolumn{2}{|c|}{ Participants } & \multicolumn{2}{|c|}{ Non-participants } \\
\hline & Mean & SE & Mean & SE \\
\hline \multicolumn{5}{|l|}{ Dependent variables } \\
\hline Maize productivity/yield (kg/ha) & 1811.27 & 179.49 & 1511.24 & 122.87 \\
\hline Maize farm income (total sales in $\mathrm{GH} \zeta$ per ha) & $1177.33^{c}$ & 116.67 & 982.3 & 79.86 \\
\hline Total household income (GHç) & $13,710.85^{\mathrm{a}}$ & 183.43 & 8239.94 & 1158.60 \\
\hline Total household income per capita (GHç) & $2222.01^{\mathrm{a}}$ & 313.36 & 788.04 & 90.04 \\
\hline \multicolumn{5}{|l|}{ Explanatory variables } \\
\hline \multicolumn{5}{|l|}{ Socio-economic characteristics } \\
\hline Gender of the household head (dummy; $1=$ male, 0 otherwise) & $0.69^{\mathrm{a}}$ & - & 0.46 & - \\
\hline Age of the household head (years) & 40.65 & 11.11 & 41.69 & 10.44 \\
\hline Household size (count) & $6.17^{\mathrm{a}}$ & 0.545 & 10.45 & 5.86 \\
\hline Number of years in formal education (years) & 6.35 & 0.58 & 5.73 & 0.59 \\
\hline Number of years in crop farming & 19.89 & 11.57 & 20.72 & 12.06 \\
\hline \multicolumn{5}{|l|}{ Plot characteristics } \\
\hline Number of maize plots (count) & $1.25^{\mathrm{b}}$ & 0.66 & 1.47 & 0.611 \\
\hline Farm size (farmland allocated to maize cultivation in ha) & $2.14^{\mathrm{a}}$ & 2.03 & 1.3 & 0.75 \\
\hline \multicolumn{5}{|l|}{ Institutional factors } \\
\hline Access to credit & 0.28 & - & 0.07 & - \\
\hline Farmer-based organization & 0.66 & & 0.73 & \\
\hline Distance to local market (kilometres) & $14.13^{c}$ & 10.22 & 16.08 & 12.12 \\
\hline Distance to regional market (kilometres) & 24.32 & 11.34 & 23.23 & 14.56 \\
\hline
\end{tabular}

a,b,c denote 1, 5 and $10 \%$ levels of significance, respectively

partly be ascribed to the over-concentration of the programme on linking farmers to the output market with the adoption of farm technology lagging.

The income from maize (measured as the total sales per hectare) shows a difference of $20 \%$ in favour of the participants which is significant at $10 \%$ level of significance. One of the key components of the ACDEP agricultural extension programme is to link farmers to the output market, and so farmers who participated in the programme might have had their products sold at the right time compared with their counterparts who did not. As part of the programme, some of the participants were engaged in contract farming where their farm product was pre-negotiated. Hence, might be responsible for the significant difference in the farm income between the participants and non-participants. The total household income is the summation of the revenues from maize and other crops, revenues from the sales of livestock and income from non-farm economic activities such as wages, salaries and other self-employed businesses earned by members of the household (e.g. household head, spouse and other economically active members). The total household income per capita defines the total income of the households relative to their size. The total household income of the ACDEP participating households is GHC 13,710, while that of the non-participants is GH\$8239 showing a significant difference between the two groups. ${ }^{4}$ Similarly, the total income per capita is GH\$2222 and GH\$788 for participants and non-participants, respectively. The large difference in household income is partly coming from the gap in the farm income, and probably the treated group were more engaged in other farming activities such as livestock rearing due to the knowledge they might have gained through the programme. The difference in household income per capita may emanate from the fact that non-participating households have a larger family size compared to the participating households. However, these descriptive statistics are limited regarding their implications for causality, as they fail to quantify and account for selectivity biases that may emanate from participation in the extension programmes.

\section{Explanatory variables}

Consistent with pieces of literature, the study hypothesized that participation in the ACDEP extension programme, as well as the determinants of farmers' farm income, can be explained by socio-economic, farmspecific and institutional factors $[9,15-17]$. Some of the

\footnotetext{
${ }^{4}$ Average exchange in 2016: GHष $=$ US $\$ 1$.
} 
socio-economic factors include gender, age, household size, the number of years in formal education and the number of years in crop farming (experience). The farmspecific factors included in the empirical models of this study are the hectare of agricultural land allocated to maize cultivation (farm size) and the number of maize farm plots. The institutional and policy variables include membership of a farmer-based organization (FBO), distance to the local district market and distance to the main regional city market as well as access to agricultural credit.

\section{Econometric technique}

The study uses a combination of three econometric techniques to assess the effects of the ACDEP agricultural extension services on farm productivity and income of the smallholder maize farmers. First, we use a simple regression referred to as regression on covariates. Second, a regression on propensity scores was used to account for selectivity bias in estimating the effects of the extension services. In the third stage, we complement the results with the Heckman treatment effect model to test the robustness of the results.

We start by considering that the outcome variables (in our case maize farm yields, farm income per capita, total household income and total household income per capita) are a linear function. This linear function consists of a vector of households, farm-specific and institutional factors $\left(X_{j}\right)$. The simplest approach to assessing the effect of the ACDEP agricultural extension programme is to include in the outcome equation ACDEP agricultural extension participation variable $\left(A E_{i}\right)$ denoting one (1) if farmer participates in the ACDEP programme and zero (0) if otherwise, and then apply ordinary least squares (OLS) estimation technique. This can be specified as:

$$
Y_{i}=\beta+\alpha_{i} A E_{i}+\delta_{i} X_{i}+\varepsilon_{i}
$$

where $Y_{i}$ is the outcome variable, $A E_{i}$ is a dummy variable for ACDEP extension programme participation, $X_{i}$ represents other explanatory variables, $\alpha_{i}$ and $\delta_{i}$ are parameters to be estimated. The causal effect of $A E_{i}$ on the outcome variables can be measured by estimating the parameter $\alpha_{i}$. However, estimating Eq. (1) with OLS might lead to biased estimates because it assumes that $A E_{i}$ is random and exogenously given, while the selection of ACDEP participants is non-random and $A E_{i}$ variable is potentially endogenous $[16,18]$. The non-random sample selection problem arises from self-selection where the farmers themselves decide whether or not to participate in the extension programme, probably due to differences in resource endowments. Thus, the selection bias emanates from the fact that treated individuals may be systematically different from the non-treated for reasons other than the treatment status. The endogeneity problem may arise becuase the programme may target farmers with specific characteristics (smallholder farmers, commercial farmers, poor farmers or relatively wealthy farmers). These may result in biased estimates of the coefficient of $A E_{i}$ which measures the effects of extension programme participation on the outcome variables. Selection bias could also arise from the selection on observable or unobservable. Selection on observables could be controlled by including some set of variables in the model. However, selection on unobservables is usually difficult to control by adding variables. This is because unobserved variables such as farmers' managerial ability, motivation, among others are not observed, hence, difficult to capture. Excluding these unobserved variables gives biased estimates of $\alpha_{i}$ in Eq. (1). The study addresses the problem of selectivity bias in three ways.

The first is to include a set of observable covariates to account for potential selection bias due to selection on observables as applied in [13]. These variables include distance to local district market, distance to regional city market and farm size. We can then re-specify Eq. (1) as:

$$
Y_{i}=\beta+\alpha_{i} A E_{i}+\chi_{i} Z_{i}+\delta_{i} X_{i}+\varepsilon_{i}
$$

where $Z_{i}$ is a vector of variables to control for the selection bias and $\chi_{i}$ is the parameter to be estimated. As stated earlier, this is called regression on covariates.

The second approach is to estimate the propensity score or conditional probability to participate in the ACDEP agricultural extension programme and use it as an additional control variable in the regression model. ${ }^{5}$ This is referred to as regression on propensity scores as used in Alemu et al. [13] and Asres et al. [19]. The propensity score as a control variable in the regression model reduces the potential biases created by selection on observable characteristics [17]. The new regression model can be specified as:

$$
Y_{i}=\beta+\alpha_{i} A E+\varphi_{i} P S_{i}+\chi_{i} Z_{i}+\delta_{i} X_{i}+\varepsilon_{i}
$$

where $P S_{i}=p\left(A E_{i}=\frac{1}{X}\right)$ and $\phi_{i}$ is the estimate of the propensity score $P S_{i}$. Other variables are defined earlier.

The third approach to deal with sample selection bias is the Heckman treatment effect model. The Heckman treatment effect model is one of the most widely used procedure to account for sample selection bias and offers a mean/way of correcting for biases that may arise from unobservable factors, and thus results in unbiased and consistent estimates [16]. The Heckman treatment effect model is an extension of the Heckman two-stage model.

${ }^{5}$ Note: A probit model was used to generate the propensity scores used in Eq. (3). 
The only difference is that the dependent variable in the selection equation becomes one of the explanatory variables in the outcome equation of the former but not in the latter model. The principle behind the treatment effect model is to estimate the selection equation (usually a probit model) and use the predicted values of the dependent variable as a selection control factor called the inverse mills ratio (IMR). The IMR is then used as an additional regressor in the outcome equation to correct sample selection and free other explanatory variables from any biases. In this way, the true effects of participation in the ACDEP agricultural extension programme on outcome variables are measured [20]. Thus, in the treatment effect model, the treatment condition enters the outcome equations as an explanatory variable to measure the true effects on the outcome variables [18].

The model can be specified in two steps. The selection equation which is usually a probit is given as:

$$
A E_{i}=\beta+\delta_{i} X_{i}+\varepsilon_{i}
$$

where $A E_{i}$ is a latent endogenous variable (participation in ACDEP agricultural extension programmes), $X_{i}$ is a set of exogenous variables determining the selection of farm households into the extension programme, $\delta_{i}$ is a parameter to be estimated and $\varepsilon_{i}$ is the error term. The substantive equation can be specified as:

$$
Y_{i}=\beta+\delta X_{i}+\alpha_{i} A E_{i}+\varepsilon_{i}
$$

where $\alpha_{i}$ measures the effect of ACDEP extension services on the outcome variables. To correct for self-selection biases in the substantive Eq. (5), an IMR denoted by the symbol $\lambda$ was generated and added as an additional explanatory variable. The formulation process of IMR is given as:

$$
\lambda=\frac{\phi\left(-\delta_{i} X\right)}{1-\Phi\left(\delta_{i} X\right)}
$$

where $\phi$ and $\Phi$ are normal probability density function and cumulative density function, respectively, of the standard normal distribution. Adding the IMR to Eq. (5) translates into Eq. (7) as:

$$
Y_{i}=\beta+\delta_{i} X_{i}+\alpha_{i} A E+\gamma_{i} \lambda_{i}+\mu_{i}
$$

where $\gamma_{i}$ is an estimate of the IMR $\left(\lambda_{i}\right)$ and $\mu_{i}$ is a twosided error term with $N\left(0, \sigma_{v}^{2}\right)$. The rest are as defined earlier. A significant coefficient of the IMR implies that there is self-selection problem, while a non-significant coefficient indicates the absence of sample selection. Ignoring the addition of the IMR will render the results from Eq. (5) as biased [21]. Thus, the inclusion of the selectivity term makes the coefficient $\alpha_{i}$ (measur-

\begin{tabular}{|c|c|c|}
\hline Variable & Coefficient & SE \\
\hline Age of the household head & $0.112^{b}$ & 0.050 \\
\hline Household size & 0.014 & 0.018 \\
\hline Number of years in formal education & -0.002 & 0.017 \\
\hline Number of years in crop farming (experience) & $0.016^{c}$ & 0.009 \\
\hline Access to agricultural credit & $0.669^{b}$ & 0.283 \\
\hline Membership of farmer-based organization (FBO) & $0.309^{b}$ & 0.149 \\
\hline Farm size allocated to maize cultivation in hectares & $0.423^{\mathrm{a}}$ & 0.107 \\
\hline Number of maize farm plots & 0.043 & 0.180 \\
\hline Constant & -1.259 & 0.373 \\
\hline $\operatorname{LRChi}^{2}(8)$ & 26.47 & \\
\hline Prob $>\mathrm{Chi}^{2}$ & 0.000 & \\
\hline Wald $\mathrm{Chi}^{2}(8)$ & 28.37 & \\
\hline Prob $>\mathrm{Chi}^{2}$ & 0.000 & \\
\hline $\begin{array}{l}\text { Sensitivity (\% correctly classified among partici- } \\
\text { pants) }\end{array}$ & $69.37 \%$ & \\
\hline $\begin{array}{l}\text { Specificity (\% correctly classified among non- } \\
\text { participants) }\end{array}$ & $69.66 \%$ & \\
\hline Total correctly classified (\%) & $69.50 \%$ & \\
\hline
\end{tabular}
ing the effects of the treatment variable on the outcome
Table 2 Determinants of participation in ACDEP agricultural extension programme

$a, b, c$ denote significance levels at 1,5 and $10 \%$, respectively

variables) unbiased, albeit it is inefficient as the disturbance term $\left(\mu_{i}\right)$ is heteroscedastic [16]. The problem of heteroscedasticity can be corrected by the use of bootstrap standard errors or re-sampling. However, the STATA software package used in generating the estimates automatically adjusts for that bias in the standard errors [22].

\section{Empirical results and discussions Determinants of ACDEP agricultural extension programme participation}

The results from the probit model for the participation in ACDEP agricultural extension programme are presented in Table 2 . The model fits the data reasonably well as indicated by the Wald test that all the coefficients are jointly equal to zero is rejected $\left[\mathrm{Chi}^{2}(8)=28.37 ; p=0.000\right]$.

The probit model also correctly classified $69.37 \%$ of the maize farm households among the participants and $69.66 \%$ among the non-participants with a total accurate prediction rate of $69.50 \%$ for the entire sample.

From the table, the probability of participating in the ACDEP extension programmes is significantly influenced by the age of the household head, the number of years in crop farming, access to agricultural credit, membership of a farmer-based organization and the size of plots allocated to maize production (farm size). The positive and significant influence of age on the probability of participation in the ACDEP agricultural extension programme is against the notion that older farmers are 
Table 3 Effects of ACDEP extension programmes on yield, farm and household income

\begin{tabular}{|c|c|c|c|c|c|c|}
\hline \multirow[t]{2}{*}{ Outcome variable } & \multicolumn{2}{|c|}{ Regression on covariates } & \multicolumn{2}{|c|}{ Regression on propensity score } & \multicolumn{2}{|c|}{$\begin{array}{l}\text { Heckman treatment } \\
\text { effects }\end{array}$} \\
\hline & Coefficient & SE & Coefficient & SE & Coefficient & SE \\
\hline Maize yield (kg/ha) & 0.011 & 0.039 & 0.012 & 0.040 & $0.113^{\mathrm{a}}$ & 0.018 \\
\hline Maize farm income (total sales in $\mathrm{GH} \zeta / \mathrm{ha}$ ) & 0.135 & 0.120 & $0.113^{c}$ & 0.063 & $1.113^{\mathrm{a}}$ & 0.192 \\
\hline Total household income (GHç) & $0.361^{\mathrm{a}}$ & 0.038 & $0.233^{\mathrm{a}}$ & 0.043 & $0.853^{\mathrm{a}}$ & 0.153 \\
\hline Total household income per capita & $0.347^{a}$ & 0.043 & $0.216^{\mathrm{a}}$ & 0.048 & $1.104^{\mathrm{a}}$ & 0.194 \\
\hline
\end{tabular}

$\overline{a, b, c}$ denote 1, 5 and $10 \%$ significance levels, respectively. SE denotes standard errors

usually reluctant to accept new information and ideas as reported by Asres et al. [19] and Genius et al. [23]. However, the result is consistent with the studies by Tiwari et al. [24] and Mendola [25]. Farmers with longer years in farming business have a higher likelihood of participating in the ACDEP programmes to optimize their farm productivity and income. Hence, the positive and significant effect of this variable is expected.

Similarly, access to agricultural credit will encourage farmers to participate in the extension programme to get more information that may help to maximize their yield to repay the credit on time. Group membership such as FBO enhances farmer-to-farmer extension services where knowledge and ideas on farm business and other off-farm activities are transferred from one farmer to the other. Thus, farmers who are members of FBOs are likely to get sufficient awareness and knowledge on farm technologies and, hence, are sensitized to join extension programme for more information on their farm business. Similarly, participants in the ACDEP agricultural extension programme tend to have larger farm sizes than their non-participants counterparts as supported by the descriptive statistics in Table 1. Usually, members of such extension programmes are encouraged to consider their farm as a business entity rather than a cultural way of life and are, therefore, poised to achieve higher output through expansion and productivity. Gebreegziabher [26] reported a positive effect of plot size on the probability of participating in an extension programme in Ethiopia.

\section{Effects of ACDEP extension programme on yield, farm income and household income}

The econometric results of the effects of the extension programme on the four outcome variables (maize productivity, farm income per hectare, total household income and total household income per capita) are reported in Table 3. These outcome variables are already defined in Table 1 . The following paragraphs discuss the effects of ACDEP agricultural extension programmes on each of the performance indicators across the three models.
Table 3 indicates that ACDEP agricultural extension programmes had positive effects on the productivity and farm income of the households in the study area. The results from different estimation approaches are quantitatively similar in terms of the direction, indicating the robustness of the results to changes in the estimation techniques. The estimated results show that the ACDEP extension programme had no significant effects on maize farm productivity when regression on covariates and regression on propensity scores were used. However, in the Heckman treatment effect model, the effect is positive and significant. Since all the variables are specified in logarithmic terms, it suggests that participating in the ACDEP extension programme has increased farm productivity by $11.3 \%$ points. The result from the Heckman model is at variance with the study of Feder et al. [27] who found no contribution of extension programmes to crop productivity. However, it is in line with other previous studies [28-31] reporting positive effects of extension programmes on crop farm productivity. The estimated effects for maize farm income per hectare vary from 0.113 to 1.13 depending on the estimation procedure. These coefficients imply that the extension programme has led to an increase in farm income by 11.3 to 111.3 percentage points. The effect is smaller in a regression on propensity score than the Heckman treatment effect model as indicated in Table 3 . The wide divergence in the magnitude of the effects may partly be attributed to the difference in the unobserved heterogeneity among the maize farm households. The regression on propensity score minimizes selection biases based on observed covariates, while Heckman treatment effects correct for selection bias arising from unobserved factors, hence, the two estimation techniques are most likely to produce different estimates. Moreover, given the market-oriented nature of the extension programmes nowadays, the large effect on farm income is not surprising. Thus, the focus is more on linking farmers to the market where products are purchased at the right time, rather than technology adoption.

For Heckman treatment effects, regression on propensity score and regression on covariate models, 
Table 4 Regression on covariates, propensity score and Heckman treatment effects (maize farm income per capita as dependent variable)

\begin{tabular}{|c|c|c|c|c|c|c|}
\hline \multirow[t]{2}{*}{ Variable } & \multicolumn{2}{|c|}{ Regression on covariates } & \multicolumn{2}{|c|}{ Regression on propensity scores } & \multicolumn{2}{|c|}{ Heckman treatment effect } \\
\hline & Coefficient & SE & Coefficient & SE & Coefficient & SE \\
\hline ACDEP extension & 0.135 & 0.120 & $0.113^{c}$ & 0.063 & $1.113^{\mathrm{a}}$ & 0.192 \\
\hline ACDEP pscore & & & $3.663^{\mathrm{a}}$ & 0.749 & & \\
\hline Distance to local market & $-0.142^{\mathrm{a}}$ & 0.029 & $-0.136^{\mathrm{a}}$ & 0.036 & & \\
\hline Distance to regional market & $-0.037^{b}$ & 0.014 & -0.019 & 0.088 & & \\
\hline Gender of household head & 0.165 & 0.138 & 0.136 & 0.131 & 0.209 & 0.121 \\
\hline Formal education & 0.009 & 0.011 & $0.024^{b}$ & 0.007 & $0.014^{\mathrm{a}}$ & 0.012 \\
\hline Household size & $0.091^{\mathrm{a}}$ & 0.011 & $-0.117^{\mathrm{a}}$ & 0.011 & $0.097^{\mathrm{a}}$ & 0.012 \\
\hline Farming experience & 0.002 & 0.006 & $0.021^{\mathrm{a}}$ & 0.007 & -0.008 & 0.006 \\
\hline Access to credit & 0.052 & 0.159 & $0.801^{\mathrm{a}}$ & 0.232 & $0.179^{b}$ & 0.018 \\
\hline Membership of FBO & 0.138 & 0.137 & 0.030 & 0.122 & $0.309^{\mathrm{a}}$ & 0.049 \\
\hline Number of maize farm plots & 0.106 & 0.093 & $0.319^{b}$ & 0.125 & -0.025 & 0.107 \\
\hline Farm size (maize) & $0.345^{\mathrm{a}}$ & 0.043 & $0.217^{\mathrm{a}}$ & 0.048 & $0.312^{\mathrm{a}}$ & 0.048 \\
\hline Constant & $6.228^{a}$ & 0.206 & $5.596 a$ & 0.235 & 6.040 & 0.234 \\
\hline Adjusted R-squared & 0.535 & & 0.585 & & & \\
\hline Lambda & & & & & 0.632 & $0.107^{\mathrm{a}}$ \\
\hline $\operatorname{LRChi}{ }^{2}(1)=13.43$ & & & & & $0.000^{*}$ & \\
\hline \multicolumn{7}{|c|}{ Breusch-Pagan/Cook-Weisberg test } \\
\hline $\operatorname{Chi}^{2}(1)$ & & 0.380 & 0.240 & & & \\
\hline Prob $>\mathrm{Chi}^{2}$ & & 0.538 & 0.622 & & & \\
\hline VIF (mean) & & 1.390 & 2.65 & & & \\
\hline Observations & 200 & & 200 & & 200 & \\
\hline
\end{tabular}

*denotes significance level of $\mathrm{LR} \mathrm{Chi}^{2}$ and it is at $1 \%$ level

$a, b, c$ denote significance levels at 1,5 and $10 \%$, respectively

extension programmes lead to $85.3 \%, 23.3 \%$ and $36.1 \%$ increase in total household income, respectively. Gebrehiwot [9] observed that extension programmes lead to $7 \%$ and $10 \%$ points in farm household income when estimated with regression on covariates and propensity score matching using stratification technique, respectively. Similarly, Asres et al. [19] reported 6\% and $18 \%$ increase in household income through participation in extension programme when estimated with OLS and Heckman treatment effects, respectively. The results also corroborate with that of [28] and [32]. The effects of ACDEP agricultural extension programmes on per capita income differ across the three models regarding the magnitudes of the effects. The extension programmes improve per capita income by $34.7 \%$ and $21.6 \%$ for regression on covariates and regression on the propensity scores, respectively. It increases by $110.4 \%$ in the Heckman treatment effect model. The greater impact of the ACDEP programme on the per capita income could emanate from the large effect of farm income coupled with the smaller household size of the participants compared with that of the nonparticipants as indicated in the descriptive statistics.
Apart from participation in extension programme, some other factors have been estimated to affect farm households' income. Table 4 presents the full results of the regression on covariates, regression on propensity scores and the second stage of the Heckman treatment model. The two regressions (regression on covariates and regression on propensity scores) are free from multicollinearity as indicated by the variance inflation factor (VIF) mean values of 1.39 and 2.65 for regression on covariates and regression on propensity scores, respectively. The VIF for each independent variable was less than the critical value of 10 indicating non-existence of multicollinearity [33]. The results are also free from heteroscedasticity as indicated by the small values of the $C h i^{2}$ generated by the Breusch-Pagan/Cook-Weisberg heteroscedasticity test.

The results indicate the significance of household locations and their effects on their farm income. The distance to market centres, both local and regional markets, is found to negatively affect their farm income. These findings may be attributed to the fact that ACDEP programmes are targeted at the remote districts and communities where poverty is pervasive. The other side is 
that farmers sometimes find it difficult in transporting their produce to the urban market centres as they are being constrained by finance and other factors such as road networks.

Other socio-economic factors such as the educational attainment (measured as the number of years in formal education), household size and farming experience (measured as the number of years in crop farming) significantly affect farm income with different estimation techniques. Similarly, institutional variables such as access to agricultural credit and social capital variable (FBO membership) are estimated to have positive and significant effects on farm income. The number of farm plots owned is positive and significant in the regression on propensity score but not significant in the regression on covariates and Heckman treatment effect model. Furthermore, the size of the plot allocated to maize production (farm size) had a positive and significant influence on farm income across the three estimation techniques. This underscores the importance of farm size to increasing farm income among smallholder rural farm households.

\section{Conclusions}

The study has assessed the effects of ACDEP agricultural extension programme on the productivity and income of farm households using primary data from two districts in the Northern region, Ghana. Since the agricultural extension programmes require a substantial amount of investment, understanding its effects on the beneficiaries (farmers) is very important. After controlling for selectivity bias, we found out that participation in the ACDEP agricultural extension programme improves welfare through an increase in farmers' income. However, the effect levels are different depending on the empirical estimation procedure adopted. The central government and development partners should commit more human, financial and logistical resources to agricultural extension delivery in the country to boost agricultural productivity, farm incomes and total household income. Also, access to agricultural credit and formation of farmer groups such as farmer-based organizations should be promoted for agricultural extension service delivery to realize its full impact.

\section{Abbreviations \\ ACDEP: Association of Church-based Development NGOs; FAO: Food and Agriculture Organization; GAP: good agricultural practices; GPRS II: growth and poverty reduction strategy II; MDG: millennium development goals; OLS: ordinary least squares; SSA: sub-Saharan Africa.}

\section{Authors' contribution}

GD-A designed the study and analysed the data. DSE collected the data and wrote the manuscript. RA revised the manuscript and conducted some additional analysis. All authors read and approved the final manuscript.

\begin{abstract}
Author details
${ }^{1}$ Department of Agricultural and Resource Economics, University for Development Studies, Tamale, Ghana. ${ }^{2}$ Department of Agricultural Economics, Agribusiness and Extension, Kwame Nkrumah University of Science and Technology, Kumasi, Ghana.
\end{abstract}

\section{Acknowledgements \\ The authors are very grateful to the enumerators who collected and assisted in the data entry and all farmers who participated in the survey. We are also grateful to the anonymous reviewers for their useful comments.}

\section{Competing interests}

The authors declare that they have no competing interests.

Availability of supporting data

The data set for this study is available from the corresponding author on request.

\section{Consent for publication}

All authors read, revised the earlier draft and approved the final manuscript.

\section{Ethical approval and consent to participate}

The authors obtained informed consent from each participant of the survey. Before starting the interview, all interviewees were informed about the context of the study and anonymous nature of the survey. Permission was sought from each respondent and they openly and freely answered the questions asked.

Funding

This study had no external funding. It was fully funded by the authors.

\section{Publisher's Note}

Springer Nature remains neutral with regard to jurisdictional claims in published maps and institutional affiliations.

Received: 21 April 2017 Accepted: 9 October 2018

Published online: 19 October 2018

\section{References}

1. Ghana Statistical Service. Ghana living standards survey round 6 (GLSS6): poverty profile in Ghana (2005-2013). Ghana: Accra; 2014.

2. Ghana Statistical Service. 2010 Population and housing census summary, report of final results. Ghana: Accra; 2012.

3. Asfaw S, Shiferaw B, Simtowe F, Lipper L. Impact of modern agricultural technologies on smallholder welfare: evidence from Tanzania and Ethiopia. Food Policy. 2012;37(3):283-95.

4. Ehiakpor SD, Danso-Abbeam G, Zutah J, Hamdiyah A. Adoption of cocoa farm management practices in Prestea Huni-Valley District, Ghana. Russ J Agric Soc Sci. 2016:5(53):117-24.

5. Wiredu AN, Zeller M, Diagne A. What determines the adoption of fertilizers among rice-producing households in Northern Ghana? Q J Int Agric. 2015;54(3):263-83.

6. Danso-Abbeam G, Setsoafia ED, Ansah IGK. Modelling farmers investment in agrochemicals: the experience of smallholder cocoa farmers in Ghana. Res Appl Econ. 2014;6(4):12-27.

7. Bruce KKA, Donkoh SA, Ayamga M. Improved rice variety and its effect on farmers' output in Ghana. J Dev Agric Econ. 2014;6(6):242-8.

8. Aneani F, Anchirinah VM, Owusu-Ansah F, Asamoah M. Adoption of some cocoa production technologies by cocoa farmers in Ghana. Sust Agric Res. 2012;1(1):103-17.

9. Gebrehiwot KG. The impact of agricultural extension on households' welfare in Ethiopia. Int J Soc Econ. 2015;42(8):733-48.

10. Christoplos I, Kidd A. Guide for monitoring, evaluation and joint analyses of pluralistic extension support. Lindau: Neuchâtel Group; 2000.

11. Food and Agriculture Organization (FAO) of the United Nations. Ethiopia Country Brief; 2010. Retrieved from www.fao.org/countries/55528/en/ eth/. 
12. Bonye SZ, Alfred KB, Jasaw GS. Promoting community-based extension agents as an alternative approach to formal agricultural extension service delivery in Northern Ghana. Asian J Agric Rural Dev. 2012;2(1):76-95.

13. Alemu AE, Maetens M, Deckers J, Bauer H, Mathijs E. Impact of supply chain coordination on honey farmers' income in Tigray, Northern Ethiopia. Agric Food Econ. 2016;4:9.

14. Swanson BE. Global review of good agricultural extension and advisory service practices. Rome: Food and Agriculture Organization of the United Nations; 2008

15. Ghana Statistical Service. 2010 Population and housing census, districts report. Ghana: Accra; 2014.

16. Greene WH. Econometric analysis. 5th ed. New Jersey: Prentice-Hall; 2003.

17. Imbens $G$. Non-parametric estimation of average treatment effects under exogeneity: a review. Rev Econ Stat. 2004;96(1):4-29.

18. Maddalla GS. Limited dependent and qualitative variables in econometrics. Cambridge: Cambridge University Press; 1983.

19. Asres E, Makoto N, Kumi Y, Akira I. Effect of agricultural extension program on smallholders' farm productivity: evidence from three peasant associations in the highlands of Ethiopia. J Agric Sci. 2013;5(8):163-81.

20. Smith J, Todd P. Does matching overcome Lalonde's critique of nonexperimental estimators? J Econ. 2005;125:305-53.

21. Heckman J. Sample selection bias as specification error. Econometrica. 1979;47:153-61.

22. Bushway S, Johnson BD, Slocum LA. Is the magic still there? The use of the Heckman two-step correction for selection bias in criminology. J Quant Criminol. 2007. https://doi.org/10.1007/s10940-007-9024-4.

23. Genius MG, Pantzios CJ, Tzouvelekas V. Information acquisition and adoption of organic farming practices. J Agric Res Econ. 2006;31(1):93-113.

24. Tiwari KR, Sitaula BK, Nyborg LP, Paudel GS. Determinants of Farmers' adoption of improved soil conservation technology in a middle mountain watershed of Central Nepal. Environ Manag. 2008;42(2):210-22.
25. Mendola M. Agricultural technology adoption and poverty reduction: a propensity score matching analysis for rural Bangladesh. Food Policy. 2007:32(33):372-93.

26. Gebregziabher G, Holden S. Does irrigation enhance and food deficits discourage fertilizer adoption in a risky environment: evidence from Tigray, Ethiopia. J Dev Agric Econ. 2011;30(10):514-28.

27. Feder G, Murgai R, Quizon JB. Sending farmers back to school: the impact of FFS in Indonesia. Rev Agric Econ. 2004;26(1):45-62.

28. Davis K, Nkonya E, Kato E, Mekonen DA, Odendo M, Miro R, Nkuba J. Impact of farmer field schools on agricultural productivity and poverty in East Africa. World Dev. 2012;40(2):402-13.

29. McGarry D. A synopsis of the measured outcomes of farmer field schools in integrated pest management for cabbage production, Timor Leste (2003-2005). FAO Brief, January 24, 2008.

30. Meti SK. Farmers field school strategies for effective diffusion of IPM technology for sustainable cotton yield: a critical analysis. Paper presented at the 23rd annual conference of the association for international agricultural and extension education, Polson, Montana, 20-24 May; 2007.

31. Geer T, Debipersaud R, Ramlall H, Settle W, Chakalall B, Joshi R. Introduction of aquaculture and other integrated pest management practices to rice farmers in Guyana and Suriname. FAN FAO Aquaculture Newsletter No. 35; 2006.

32. Kelemework, F. Impact evaluation of farmer field school: the case of integrated potato late blight management in the Central Highland of Ethiopia. University of Antwerp (Thesis); 2005.

33. Gujarati DN, Porter DC. Basic econometrics. 5th ed. Irwin: McGraw-Hill; 2009
Ready to submit your research? Choose BMC and benefit from:

- fast, convenient online submission

- thorough peer review by experienced researchers in your field

- rapid publication on acceptance

- support for research data, including large and complex data types

- gold Open Access which fosters wider collaboration and increased citations

- maximum visibility for your research: over $100 \mathrm{M}$ website views per year

At $\mathrm{BMC}$, research is always in progress.

Learn more biomedcentral.com/submissions 